\title{
IDENTIFIKASI JENIS DAN NILAI PEMANFAATAN SUMBERDAYA MANGROVE DI TELUK KUPANG, PROPINSI NUSA TENGGARA TIMUR
}

\author{
Oleh \\ Andrian Ramadhan ${ }^{1)}$ dan Sachivitra Savitri'
}

\begin{abstract}
Penelitian ini dilakukan pada bulan Agustus tahun 2006. Tujuan penelitian ini adalah untuk mengidentifikasi jenis dan nilai pemanfaatan sumberdaya mangrove di Teluk Kupang, Nusa Tenggara Timur. Pendekatan yang digunakan adalah penelitian survei. Data yang diperoleh dianalisis secara deskriptif dan kuantitatif. Hasil yang didapat bahwa jenis pemanfaatan sumberdaya mangrove terdiri dari penangkapan sumberdaya ikan, pemanfaatan sumberdaya kayu dan pemanfaatan lahan untuk kegiatan tambak bandeng dan garam. Total nilai pemanfaatan mangrove adalah sebesar Rp. 171.415.954./ha/tahun. Perikanan tangkap memberikan kontribusi terbesar yaitu mencapai 98 persen, sehingga dapat dikatakan bahwa sumberdaya mangrove merupakan sumber pendapatan terpenting bagi masyarakat yang tinggal disekitarnya. Oleh karena itu kebijakan dalam pengelolaan sumberdaya pesisir, khususnya menyangkut perubahan pemanfaatan wilayah, perlu mempertimbangkan dampak sosial ekonomi yang akan terjadi terhadap masyarakat.
\end{abstract}

\section{Kata Kunci : Potensi, Manfaat, Mangrove, Teluk Kupang, Nusa Tenggara Timur}

\begin{abstract}
Identification of Utilization and Benefit Value of Mangrove at Kupang Bay, East Nusa Tenggara Province by Andrian Ramadhan and Sachivitra Savitri

Research was conducted on August 2006. The aim of the research were to identify the utilization and benefit valueof mangrove at Kupang Bay, East Nusa Tenggara Province. Survey research approach was used in this research and data were analyzed descriptively and quantitatively. The result showed that mangrove were utilized for capture fisheries, wood sources and land exploitation for milk fish and salt production. Economic value of mangrove was Rp. 167.402.305/ha/year. Capture fisheries are the largest contribution, up to 98 percent. Mangrove is the most important income source for society in Kupang Bay who live in the vicinity. Therefore coastal management policy was required to be developed by considering the impact on socio economics of mangrove utilization on community at Kupang Bay, especially related to coastal utilizatin area change.
\end{abstract}

Key Word : Potency, Benefit, Mangrove, Kupang Bay, East Nusa Tenggara

\footnotetext{
${ }^{1)}$ Peneliti Pada Balai Besar Riset Sosial Ekonomi Kelautan dan Perikanan, BRKP-DKP. JI. KS TUBUN Petamburan VI Slipi Jakarta 10260. Telp. (021)53650162.e-mail : ianipb@yahoo.com

${ }^{2)}$ Pusat Riset Teknologi Kelautan, BRKP-DKP. JI. M.T. Haryono. Jakarta
} 


\section{PENDAHULUAN}

Sumberdaya mangrove sudah lama dimanfaatkan oleh masyarakat di sekitar Teluk Kupang untuk berbagai keperluan, baik keperluan sandang, pangan maupun papan. Berbagai cara pemanfaatan tumbuh dan berkembang ditengah-tengah masyarakat. Aktivitas yang ada tidak terbatas pada kegiatan yang bersifat perburuan atau penangkapan tetapi juga kegiatan budidaya yang memanfaatkan kesesuaian kondisi kawasan mengrove untuk tambak bandeng serta garam.

Aktivitas masyarakat yang memanfaatkan sumberdaya mangrove sebagaimana disebutkan diatas memberikan nilai manfaat yang cukup besar. Lebih jauh Fauzy (2003) mendefinisikan nilai manfaat sebagai suatu upaya untuk mengkuantifikasi sumberdaya alam kedalam nilai uang, terlepas dari nilai pasar atau nilai non pasar. Sedangkan nilai manfaat langsung adalah nilai yang mencerminkan tingkat manfaat yang digunakan oleh masyarakat secara langsung dari keberadaan mangrove tersebut.
Penelitian ini bertujuan untuk mengetahui jenis-jenis pemanfaatan sumberdaya mangrove yang terdapat di Teluk Kupang dan menghitung nilai manfaat yang secara langsung dirasakan oleh masyarakat. Penelitian ini penting dilakukan sehingga dapat mengisi kekurangan informasi dalam perumusan rencana pengelolaan sumberdaya mangrove di Teluk Kupang. Selain pemerintah, informasi yang dihasilkan oleh penelitian ini juga menjadi sumber informasi bagi kalangan usahawan setempat untuk mengembangkan kawasan mangrove di Teluk Kupang.

\section{METODE}

\section{Lokasi dan Waktu Penelitian}

Penelitian di lakukan pada Desa Sulamu, Pariti, Oeteta, dan Oebelo yang terletak di Teluk Kupang, Kabupaten Kupang, Nusa Tenggara Timur pada bulan Agustus tahun 2006 (Gambar 1). Lokasi penelitian ditentukan berdasarkan daerah yang memiliki kawasan mangrove cukup baik dan telah banyak dimanfaatkan oleh masyarakat untuk berbagai kebutuhan.

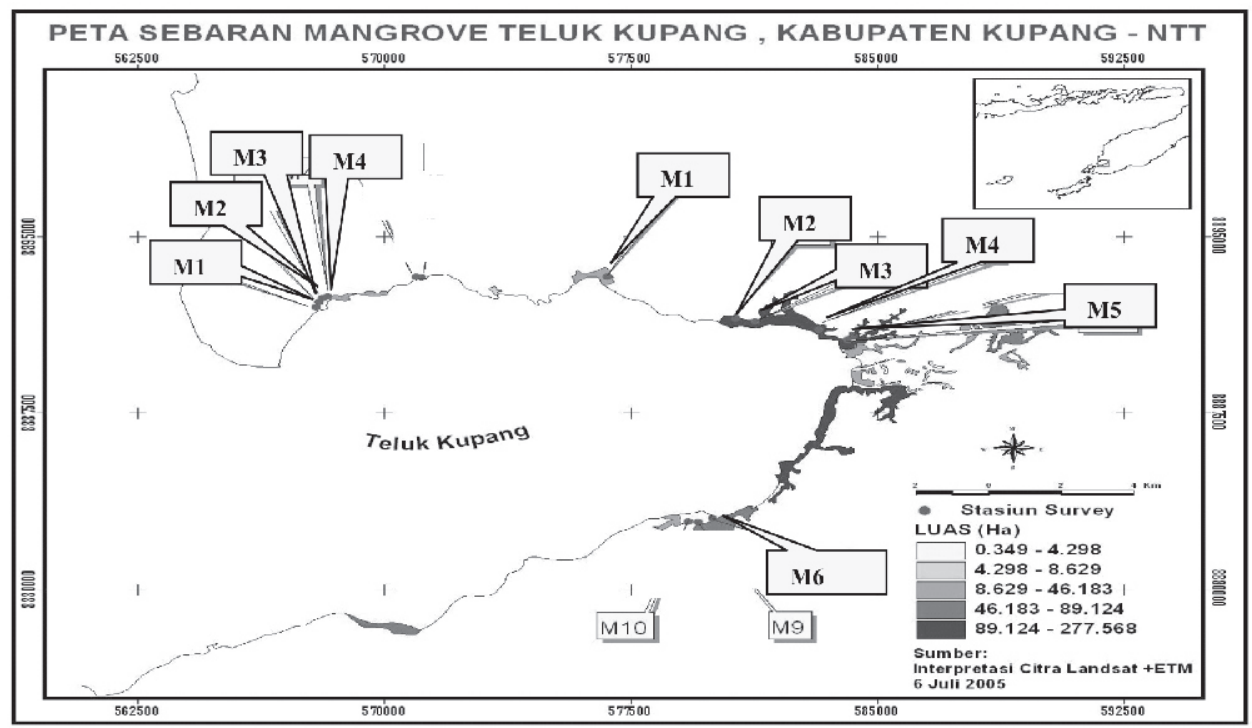

Gambar 1. Lokasi Penelitian di Wilayah Teluk Kupang, Nusa Tenggara Timur (Sumber : Interpretasi Citra Landsat + ETM 6 Juli 2005)

Figure 1. Research Location in Kupang Bay Area, East Nusatenggara (Source: Landsat Image Interpretation + ETM, July 6, 2005) 


\section{Pengumpulan Data}

Jenis data yang dikumpulkan pada penilitian ini adalah data primer dan sekunder. Data primer dikumpulkan dengan melakukan pengamatan dan wawancara terhadap masyarakat dalam memanfaatkan sumberdaya mangrove. Wawancara dilakukan secara tertutup dengan bantuan kuesioner yang telah disesuaikan dengan tujuan penelitian. Masyarakat yang dipilih menjadi responden adalah mereka yang melakukan pemanfaatan sumberdaya perikanan, pemanfaatan sumberdaya kayu, dan pemanfaatan lahan di sekitar wilayah mangrove. Pemanfaatan sumberdaya perikanan pada penelitian ini dibatasi pada kegiatan penangkapan ikan, udang, kerang dan kepiting yang dilakukan disekitar wilayah mangrove. Pemanfaatan sumberdaya kayu meliputi pemanfaatan untuk kayu bakar dan pembuatan alat tangkap sero waring. Sedangkan pemanfaatan lahan disekitar mangrove meliputi tambak bandeng dan tambak garam.

Data sekunder diperoleh dari penelusuran hasil studi sebelumnya serta data statistik dalam aspek perikanan baik di tingkat Kabupaten maupun Kecamatan. Sumber data diperoleh dari berbagai pihak yaitu Bappeda Kabupaten Kupang, Universitas Nusa Cendana, Badan Pusat Statistik, Dinas Perikanan dan Kelautan Kabupaten Kupang, Kecamatan Sulamu dan Kupang Tengah. Selain itu juga dilakukan pengamatan citra satelit untuk mengestimasi luas mangrove yang terdapat diwilayah Teluk Kupang.

\section{Analisis Data}

Data dianalisis secara deskriptif dan kuantitatif. Analisis data secara deskriptif digunakan untuk menjelaskan aktivitas masyarakat yang memanfaatkan sumberdaya mangrove. Analisis data kuantitatif digunakan untuk menghitung nilai manfaat sumberdaya mangrove yang dirasakan secara langsung oleh masyarakat. Manfaat secara langsung sumberdaya mangrove terhadap masyarakat digambarkan oleh Gunarto sebagai sumber bahan bakar (kayu, arang), bahan bangunan (balok, papan), serta bahan tekstil, makanan, dan obat-obatan. Nilai manfaat langsung di estimasi dengan menghitung jumlah ekstraksi langsung dari sumberdaya alam dan nilai yang terkait dengan menggunakan harga pasar. Menurut McCracken and Abaza dalam Kusuma (2005) harga pasar yang umum digunakan adalah harga pasar lokal (local market prices) dan mengikuti formula :

Nilai Pemanfaatan Sumberdaya Mangrove $=$ $\sum\left(\mathrm{T}_{\mathrm{i}} \times \mathrm{H}_{\mathrm{i}}\right)-\mathrm{B}_{\mathrm{i}}$

Dimana:

$\begin{aligned} \mathrm{H}_{\mathrm{i}}= & \text { Harga jenis sumberdaya ke }-\mathrm{i} / \\ & \text { Resource Price (Rp/ton) } \\ \mathrm{T}_{\mathrm{i}}= & \text { Jumlah jenis Pemanfaatan } \\ & \text { sumberdaya ke }-\mathrm{i} / \text { Number of } \\ & \text { Resource Utilization (ton/tahun) } \\ \mathrm{B}_{\mathrm{i}}= & \text { Biaya operasional pemanfaatan } \\ & \text { sumberdaya ke }-\mathrm{i} \text { (Rp/tahun) } \\ & \text { Operational Cost of Resource } \\ & \text { Utilization (Rp/year) }\end{aligned}$

Pendekatan produktivitas (effect on production) digunakan untuk mengukur nilai manfaat sumberdaya baik dalam bentuk barang maupun jasa selama periode waktu tertentu (Adrianto, 2006). Secara lebih spesifik pendekatan yang digunakan adalah residual rent. Residual rent melihat kontribusi sistem alam atau faktor pendapatan (faktor income) terhadap nilai ekonomi total. Perhitungan matematis residual rent dapat ditulis sebagai berikut :

PV Residual Rent Model $\left[\sum_{t=0}^{T} \frac{B t-C t}{(1+r)^{t}}\right]$

Keterangan :

$L$

$\mathrm{Bt}=$ Manfaat sumberdaya $/$ Benefit Production

$\mathrm{Ct}=$ Biaya produksi $/$ Cost Production

$\mathrm{T}$ = Jumlah tahun proyeksi / Total Cost Projection

$r \quad=$ Tingkat diskon riil / Level of discount rate

$\mathrm{L}$ = Luas Kawasan Sumberdaya / Resource area 


\section{HASIL DAN PEMBAHASAN}

\section{Kondisi Umum Mangrove di Teluk Kupang}

Pesisir Teluk Kupang merupakan daerah yang memiliki banyak kawasan mangrove dengan ketebalan yang masih relatif baik khususnya pada bagian wilayah timur. Mangrove tumbuh cukup tebal pada wilayah timur, dan masih memberikan manfaat yang cukup besar bagi masyarakat. Pada daerah sebelah barat dimana lebih dekat dengan kota, kondisi mangrove sudah tidak terlalu tebal. Sebagian wilayah pesisir pada bagian barat Teluk Kupang telah beralih fungsi menjadi tempat wisata, kawasan perumahan penduduk, pertokoan dan lain-lain.

Panjang garis pantai di Teluk Kupang diperkirakan mencapai $17.578 \mathrm{~m}$ dengan luas total diperkirakan mencapai 1.106 ha. Panjang garis pantai pada lokasi penelitian cukup beragam yaitu antara $1.170 \mathrm{~m}$ sampai dengan $4.370 \mathrm{~m}$ dengan pantai terpanjang terletak pada Desa Oeteta. Ketebalan mangrove juga sangat bervariasi mulai dari $45 \mathrm{~m}$ sampai dengan $650 \mathrm{~m}$. Desa yang memiliki mangrove dengan tingkat ketebalan yang paling besar adalah pada Desa Oebelo yang memiliki ketebalan antara $150 \mathrm{~m}$ sampai dengan 300 $\mathrm{m}$. Estimasi luas mangrove pada daerah penelitian mencapai 194,87 ha. Desa yang memiliki luasan mangrove terbesar adalah pada Desa Oeteta yang mencapai 98,33 ha (Tabel 1).

\section{Pemanfaatan Sumberdaya Perikanan Tangkap}

Keberadaan stok sumberdaya perikanan sangat dipengaruhi oleh keberadaan mangrove yang memiliki fungsi sebagai tempat penyedia pakan, pembesaran, dan tempat pemijahan. Dengan demikian semakin baik kondisi mangrove mengindikasikan suburnya wilayah perairan akan sumberdaya perikanan.

Kegiatan penangkapan ikan dan udang di wilayah sekitar mangrove pada Teluk Kupang didominasi oleh alat tangkap sero waring. Sero waring adalah alat tangkap yang dipasang pada sepanjang pinggir pantai dan berfungsi sebagai perangkap ikan dan udang dengan memanfaatkan kondisi pasang surut air laut. Ukuran mata jaring yang digunakan adalah $2 \mathrm{~mm}$ yang menyebabkan ikan-ikan berukuran kecil terjaring termasuk nener bandeng dan benur udang.

Penangkapan ikan di Desa Oebelo menggunakan alat tangkap yang relatif beragam. Sebagian besar masyarakat menggunakan alat tangkap pancing, jaring dan serok yang bersifat aktif. Jumlah hasil tangkapan ikan disekitar pantai Desa Oebelo rata-rata berjumlah $11,25 \mathrm{Kg}$ dengan harga rata-rata ikan adalah Rp. 8.750 per kilogram. Dalam kegiatan penangkapan ikan di Desa Oebelo, biaya operasional yang harus dikeluarkan mencapai Rp. 70.000 per trip. Biaya tersebut dipergunakan untuk biaya

Tabel 1. Panjang Garis Pantai, Ketebalan dan Estimasi Luas Mangrove pada Lokasi Penelitian Tabel 1. Coast Line Lenght, Thickness and Estimation of Mangrove Area at Research Location

\begin{tabular}{clrrrr}
\hline No & $\begin{array}{c}\text { Nama Desa/ } \\
\text { Village }\end{array}$ & $\begin{array}{c}\text { Panjang Garis } \\
\text { Pantai (meter)/ } \\
\text { Coast Line } \\
\text { Length }(\boldsymbol{m})\end{array}$ & $\begin{array}{c}\text { Tebal (meter)/ } \\
\text { Thickness } \\
\text { (Meter) }\end{array}$ & $\begin{array}{c}\text { Lokasi/ } \\
\text { Location }\end{array}$ & $\begin{array}{c}\text { Estimasi Luas } \\
\text { Mangrove(ha)/ } \\
\text { Estimation of } \\
\text { Mangrove } \\
\text { Area (ha) }\end{array}$ \\
\hline 1 & Pariti & 1.170 & $100-480$ & $\mathrm{M} 1$ & 33,94 \\
2 & Oeteta & 4.370 & $150-300$ & $\mathrm{M} 2-\mathrm{M} 5$ & 98,33 \\
3 & Oebelo & 1.565 & $150-650$ & $\mathrm{M} 6$ & 62,60 \\
& Total & & & & 194,87 \\
\hline
\end{tabular}


Tabel 2. Nilai Hasil Tangkapan Ikan Pada Perairan Sekitar Mangrove Table 2. Fish Catch Value at Mangrove Waters Area

\begin{tabular}{rlrrrr}
\hline No & $\begin{array}{c}\text { Desa/ } \\
\text { Village }\end{array}$ & $\begin{array}{c}\text { Hasil } \\
\text { Tangkapan } \\
\text { (ton) / Catched } \\
\text { Revenue (ton) }\end{array}$ & $\begin{array}{c}\text { Harga rata-rata } \\
\text { hasil tangkapan } \\
\text { (Rp/kg) / Price } \\
\text { Rates Catched } \\
\text { Revenue (Rp/kg) }\end{array}$ & $\begin{array}{c}\text { Total Biaya } \\
\text { Operasional } \\
\text { (Rp/tahun) / Total } \\
\text { Operational Cost }\end{array}$ & $\begin{array}{c}\text { Nilai Manfaat } \\
\text { Penangkapan Ikan } \\
\text { (Rp/tahun) / } \\
\text { Benefit Fish } \\
\text { Catched Value }\end{array}$ \\
\hline 1 & Pariti & 191 & 5.167 & - & 987.026 .175 \\
2 & Oeteta & 247,7 & 5.000 & - & 1.238 .625 .000 \\
3 & Oebelo & 388,8 & 8.750 & 2.471 .040 .000 & 930.960 .000 \\
\hline \multicolumn{7}{r}{ Total } & & & & 3.156 .611 .175 \\
\hline
\end{tabular}

bahan bakar dan perbekalan untuk dua orang. Selain dari biaya melaut, terdapat juga biaya untuk perbaikan mesin dan alat tangkap yang rata-rata berjumlah Rp. 228.000 perbulan (Tabel 2).

Musim penangkapan udang pada perairan pesisir Teluk Kupang terjadi pada saat musim hujan yang pada beberapa tahun terakhir berlangsung antara bulan Oktober sampai dengan bulan April. Jumlah tangkapan harga udang untuk jenis udang windu dapat mencapai Rp. 45.000/kg, udang putih sebesar Rp. 35.000/kg sedangkan udang merah Rp. $20.000 / \mathrm{kg}$. Sedangkan pada saat musim hujan harga udang turun menjadi Rp. 30.000 - Rp. $35.000 / \mathrm{Kg}$ untuk udang windu, Rp. $20.000 / \mathrm{Kg}$ - Rp. 25.000/ Kg untuk udang putih dan Rp. 10.000 - Rp. 15.000 untuk udang merah. Nilai produksi dari kegiatan penangkapan udang dapat dilihat pada Tabel 3.

Tabel 3. Nilai Hasil Tangkapan Udang Pada Perairan Sekitar Mangrove

Table 3. Shrimp Catch Value at Mangrove Waters Area

\begin{tabular}{|c|c|c|c|c|c|c|}
\hline \multirow[b]{2}{*}{ No } & \multirow[b]{2}{*}{$\begin{array}{l}\text { Desa/ } \\
\text { Village }\end{array}$} & \multicolumn{2}{|c|}{$\begin{array}{l}\text { Musim Panas I } \\
\text { Summer }\end{array}$} & \multicolumn{2}{|c|}{$\begin{array}{c}\text { Musim Hujan I } \\
\text { Winter }\end{array}$} & \multirow{2}{*}{$\begin{array}{c}\text { Nilai Manfaat } \\
\text { Penangkapan } \\
\text { Udang } \\
\text { (Rp/tahun)/ } \\
\text { Benefit Value of } \\
\text { Shrimp } \\
\text { Catching } \\
\text { (Rp/tahun) }\end{array}$} \\
\hline & & $\begin{array}{c}\text { Hasil } \\
\text { Tangkapan } \\
\text { (ton) / Catch } \\
\text { Revenue }\end{array}$ & $\begin{array}{c}\text { Harga Rata- } \\
\text { rata }(\text { Rp/kg) I } \\
\text { Price Rates } \\
(R p / k g)\end{array}$ & $\begin{array}{c}\text { Hasil } \\
\text { Tangkapan } \\
\text { Musim Hujan } \\
\text { (ton)/ Catch } \\
\text { Revenue on } \\
\text { Winter }\end{array}$ & $\begin{array}{c}\text { Harga rata- } \\
\text { rata musim } \\
\text { hujan } \\
\text { (Rp/kg)/Price } \\
\text { Rates on } \\
\text { Winter }\end{array}$ & \\
\hline 1 & Pariti & 56,6 & 29.166 & 990,7 & 16.666 & 18.162 .468 .333 \\
\hline 2 & Oeteta & 51,6 & 32.500 & $1.252,4$ & 23.750 & 31.421 .507 .812 \\
\hline \multirow[t]{2}{*}{4} & Oebelo & - & - & 170 & 21.875 & 3.720 .937 .500 \\
\hline & Total & & & & & 53.304 .913 .645 \\
\hline
\end{tabular}

udang akan meningkat secara signifikan pada saat musim hujan yaitu dari rata-rata tangkapan $0,98 \mathrm{~kg} /$ hari pada saat musim panas menjadi sebesar $13,33 \mathrm{~kg} /$ hari pada saat musim hujan. Harga udang juga berfluktuasi seiring dengan jumlah hasil tangkapan. Pada musim panas dimana ketersediaan pasokan udang cukup terbatas,
Kepiting merupakan salah satu komoditas yang memiliki nilai ekonomi tinggi dalam sumberdaya mangrove. Harga kepiting perkilogram di tingkat nelayan sebesar Rp.15.000. Penangkapan kepiting dilakukan dengan menggunakan pancing dan sorok. Waktu penangkapan biasa dilakukan pada waktu menjelang sore. Jenis kepiting yang 
Tabel 4. Nilai Hasil Tangkapan Kepiting Pada Wilayah Mangrove di Teluk Kupang

Table 4. Crab Catch Value at Mangrove Area in Kupang Bay

\begin{tabular}{rlrrr}
\hline No & $\begin{array}{c}\text { Desa/ } \\
\text { Village }\end{array}$ & $\begin{array}{c}\text { Hasil } \\
\text { Tangkapan } \\
\text { (ton)/Catched } \\
\text { Revenue (ton) }\end{array}$ & $\begin{array}{c}\text { Harga rata-rata } \\
\text { hasil tangkapan } \\
\text { (Rp/Kg)/ Price } \\
\text { Rates of Catched } \\
\text { Revenue (Rp/kg) }\end{array}$ & $\begin{array}{c}\text { Nilai Manfaat } \\
\text { Penangkapan Kepiting } \\
\text { (Rp/ton) / Benefit Value of } \\
\text { Crab Catched (Rp/ton) }\end{array}$ \\
\hline 1 & Pariti & 2,5 & 15.000 & 37.440 .000 \\
2 & Oeteta & 4,2 & 15.000 & 62.400 .000 \\
3 & Sulamu & - & - & - \\
4 & Oebelo & 4,2 & 11.000 & 46.475 .000 \\
& Total & & & 146.315 .000 \\
\hline
\end{tabular}

ditangkap adalah kepiting bakau (Scylla sp.) yang banyak hidup di lumpur-lumpur mangrove. Rata-rata tangkapan nelayan perhari hanya sekitar $3,25 \mathrm{Kg}$. Kecilnya jumlah tangkapan kepiting lebih disebabkan tidak adanya saluran pemasaran yang baik, sehingga penangkapan kepiting lebih ditujukan untuk keperluan konsumsi seharihari. Bagi masyarakat yang lebih kental dengan budaya bertani, penangkapan kepiting hanya merupakan kegiatan sambilan dan bukan prioritas untuk dilakukan. Penangkapan kepiting setiap hari dilakukan oleh sekitar 5-10 orang pada Desa Pariti dan Oeteta, 3-5 orang pada Desa Oebelo (Tabel 4).

Tipe tanah mangrove yang berlumpur, merupakan tempat hidup yang sesuai bagi berbagai jenis kerang. Jenis kerang yang paling banyak di temui adalah jenis kerang dara (Anadara sp). Penangkapan kerang biasa dilakukan pada saat menjelang petang dengan hanya mengunakan bantuan ember sebagai wadah penampung hasil tangkapan. Pada saat menjelang petang air akan surut atau yang dalam bahasa lokal disebut sebagi meting dan mamok. Meting adalah kondisi dimana air laut surut maksimal yang dapat mencapai $3 \mathrm{Km}$ dari pinggir pantai dan terjadi pada awal bulan dan ketika bulan purnama. Sedangkan mamok adalah meting kecil dimana surutnya air hanya beberapa ratus meter dari pinggir pantai. Hasil tangkapan kerang pada saat mamok adalah sekitar 3-5 $\mathrm{Kg}$ dan pada saat meting dapat mencapai 10$15 \mathrm{Kg}$. Kerang yang dijual hanya sekitar 20 persen dari total tangkapan selebihnya untuk dikonsumsi sendiri. Harga jual kerang adalah Rp. 2.000 per Kg (Tabel 5). Penangkapan kerang banyak dilakukan oleh ibu-ibu rumah tangga yang dibantu oleh anak-anak. Jumlah masyarakat yang melakukan penangkapan kerang pada saat mamok di Desa Pariti dan

Tabel 5. Nilai Hasil Tangkapan Kerang Pada Wilayah Mangrove di Teluk Kupang

Table 5. Shell Catch Value at Mangrove Area in Kupang Bay

\begin{tabular}{rlrrr}
\hline No & $\begin{array}{c}\text { Desa/ } \\
\text { Village }\end{array}$ & $\begin{array}{c}\text { Hasil tangkapan } \\
\text { (ton)/Catched } \\
\text { Revenue (ton) }\end{array}$ & $\begin{array}{c}\text { Harga rata-rata hasil } \\
\text { tangkapan (Rp/Kg)/ } \\
\text { Price Rates of } \\
\text { Catched Revenue } \\
\text { (Rp/kg) }\end{array}$ & $\begin{array}{c}\text { Nilai Manfaat Penangkapan } \\
\text { Kerang (Rp/tahun)/ Benefit } \\
\text { Value of Shell Catched } \\
\text { (Rp/tahun) }\end{array}$ \\
\hline 1 & Pariti & 9 & 2.000 & 18.000 .000 \\
2 & Oeteta & 18 & 2.000 & 36.000 .000 \\
3 & Oebelo & 8 & 2.000 & 16.000 .000 \\
& Total & & & 140.000 .000 \\
\hline
\end{tabular}


Oeteta masing-masing berjumlah kurang lebih 10 orang. Sedangkan pada saat meting, jumlah penangkap kerang dapat mencapai dua kali-tiga kali lipat dari waktu mamok. kering dimanfaatkan sebagai bahan bakar untuk keperluan masak setiap hari. Semenjak adanya larangan menggunakan kayu mangrove kecuali yang sudah kering dan jatuh ke tanah, pemanfaatan kayu untuk keperluan

Tabel 6. Nilai Hasil Pemanfaatan Kayu Sebagai Alat Tangkap Sero Waring

Table 6. Benefit Value of Wood Utilization as Sero Waring Catching Gear

\begin{tabular}{rlrrrr}
\hline No & $\begin{array}{c}\text { Desa / } \\
\text { Village }\end{array}$ & $\begin{array}{c}\text { Jumlah Sero } \\
\text { Waring I } \\
\text { Number of } \\
\text { Sero Waring }\end{array}$ & $\begin{array}{c}\text { Rata-rata Kayu } \\
\text { tegakan yang } \\
\text { digunakan } \\
\text { (batang) / } \\
\text { Average Number } \\
\text { of Stand Suport } \\
\text { Wood (Stick) }\end{array}$ & $\begin{array}{c}\text { Harga Kayu } \\
\text { Tegakan (Rp/ } \\
\text { Batang)/ } \\
\text { Price of Stand } \\
\text { Wood } \\
\text { (Rp/Stick) }\end{array}$ & $\begin{array}{c}\text { Nilai Manfaat } \\
\text { (Rp/tahun)/ } \\
\text { Benefit Value } \\
\text { (Rp/year) }\end{array}$ \\
\hline 1 & Pariti & 283 & 425 & 1.000 & 120.275 .000 \\
2 & Oeteta & 367 & 425 & 1.000 & 155.975 .000 \\
3 & Oebelo & - & - & - & \\
\hline
\end{tabular}

\section{Pemanfataan Sumberdaya Kayu}

Kayu mangrove telah lama dimanfaatkan oleh masyarakat untuk berbagai kebutuhan. Pohon mangrove yang berukuran besar dimanfaatkan sebagai bahan dasar pembuatan perahu-perahu nelayan dan sebagai bahan bangunan. Pohon mangrove yang berukuran kecil dan lurus seperti Ceriops dimanfaatkan sebagai tiang penyangga pada lengan sero waring dan kantong utama yang banyak dipasang di sepanjang pantai. Sedangkan kayu-kayu mangrove yang sudah bahan bangunan dan pembuatan perahu nelayan sudah tidak lagi dilakukan. Pemanfaatan kayu untuk penyangga sero saat ini masih banyak dilakukan, meskipun sudah terdapat nelayan yang menggantinya dengan pohon bambu dan kayu-kayu dari hutan daratan. Jumlah batang kayu yang dibutuhkan untuk satu sero waring bervariasi berkisar antara 350-500 batang tergantung dari besar sero waring yang dibangun (Tabel 6.). Bila pemakaian kayu ini terus berlanjut, dikhawatirkan dapat menyebabkan semakin

Tabel 7. Nilai Hasil Pemanfaatan Kayu Bakar

Table 7. Benefit Value of Firewood

\begin{tabular}{cccccc}
\hline No & $\begin{array}{c}\text { Jumlah } \\
\text { Kepala } \\
\text { Keluarga/ } \\
\text { Vumber of } \\
\text { Vouseholder }\end{array}$ & $\begin{array}{c}\text { Rata-rata } \\
\text { Penggunaan Kayu } \\
\text { Bakar (Ikat/ } \\
\text { Tahun/KK) / } \\
\text { Average Utilization } \\
\text { of Firewood } \\
\text { (Bunch/Year/KK) }\end{array}$ & $\begin{array}{c}\text { Harga Kayu } \\
\text { Bakar Per } \\
\text { Ikat / } \\
\text { Price of } \\
\text { Firewood per } \\
\text { Bunch }\end{array}$ & $\begin{array}{c}\text { Nilai Manfaat } \\
\text { Kayu Bakar } \\
\text { (Rp/tahun)/ } \\
\text { Benefit value of } \\
\text { Firewood } \\
\text { (Rp/Year) }\end{array}$ \\
\hline 1 & Pariti & 680 & 156 & 1.000 & 109.330 .000 \\
2 & Oeteta & 456 & 175.5 & 1.000 & 71.136 .000 \\
3 & Oebelo & 841 & 193 & 1.000 & 225.424 .000 \\
\hline \multicolumn{7}{r}{ Total } & & & & 525.230 .000 \\
\hline
\end{tabular}


berkurangnya jumlah tegakan pohon mangrove yang ada. Sehingga dalam jangka waktu yang lama akan menekan keberadaan sumberdaya mangrove.

Seluruh masyarakat yang tinggal didesa masih menggunakan kayu kering sebagai bahan bakar untuk keperluan masak seharihari. Rata-rata kepala keluarga mengambil kayu sebanyak 2,5 ikat kayu kering untuk penggunaan selama 2 sampai dengan 3 hari. Satu ikat terdiri dari 15 batang dengan diameter rata-rata $5 \mathrm{~cm}$ dan panjang $100 \mathrm{~cm}$ dengan harga sebesar Rp. 1.000.

\section{Pemanfaatan Lahan di Sekitar Mangrove}

Pada wilayah mangrove terdapat hamparan lahan yang cukup luas dimana tidak ditumbuhi oleh pohon-pohon mangrove yang biasa disebut harak. Menurut masyarakat harak terjadi karena terdapat perbedaan tinggi permukaan pada lahan mangrove. Lahanlahan yang lebih tinggi dari daerah lainnya sering tidak tergenangi oleh air dan kemudian tanaman disekitarnya menjadi kering. Karena terjadi dalam waktu yang lama, wilayah yang kering meluas dan terbentuklah harak.

Pemanfaatan lahan disekitar mangrove termasuk harak untuk tambak bandeng baru dilakukan di Desa Pariti. Luas lahan tambak bandeng yang terdapat pada Desa Pariti saat ini adalah $27 \mathrm{Ha}$. Lahan tambak pertama kali dibuka pada tahun 1990-an. Teknologi yang digunakan masih cukup sederhana dan tanpa pemberian pakan tambahan. Perlakuan hanya terhadap tambak hanya dilakukan ketika masa persiapan dengan mengolah kembali tanah tambak yang baru dipanen dan diberi tambahan pupuk TSP dan pupuk kandang. Padat tebar yang dilakukan adalah sebanyak 5.000 ekor benih/ha. Rata-rata panen dilakukan pada usia pemeliharaan selama enam bulan dengan hasil mencapai 2 ton/ha. Harga perkilogram Bandeng adalah sebesar Rp. 5.000/ Kg. Tambak bandeng meskipun masih dilakukan secara sederhana, memberikan keuntungan dan manfaat yang cukup besar bagi masyarakat. Dari total lahan tambak seluas $27 \mathrm{Ha}$ dapat dihasilkan produksi bandeng sebanyak 108 ton per tahun. Total nilai produksi tambak bandeng adalah sebesar Rp. 540.000.000. pertahun. Total biaya operasional tambak bandeng mencapai Rp. 97.835.294 pertahun. Dengan demikian nilai manfaat total dari tambak bandeng adalah sebesar Rp. 442.164.706.

Tambak garam terdapat di Desa Oeteta yang memanfaatkan lahan harak. Kegiatan tambak garam yang saat ini ada merupakan proyek percontohan pemerintah untuk memanfaatkan lahan-lahan tidur yang memiliki potensi secara ekonomi. Luasan harak yang telah dimanfaatkan sebagai tambak garam adalah seluas $7 \mathrm{Ha}$. Produksi garam hanya dilakukan ketika musim panas atau kering. Lama musim panas di Kabupaten Kupang dapat mencapai 7 bulan tiap tahunnya. Musim hujan terjadi dalam waktu yang relatif pendek, yaitu sekitar bulan Desember sampai dengan bulan April. Lamanya musim panas atau kering di Kabupaten Kupang dipengaruhi oleh adanya angin muson.

Berdasarkan data Direktorat Jenderal perindustrian dan perdagangan (Anonim, 1999). Kapasitas produksi lahan tabak garam per 5 Ha yang memiliki musim panas antara 6 sampai dengan 7 bulan adalah sebesar 525 ton atau 105 ton per Ha. Harga garam dimuka gudang adalah sebesar Rp. 126.000/ ton. Atas dasar estimasi produksi garam dan harga jual yang berlaku maka diketahui nilai produksi tambak garam di Desa Oeteta adalah sebesar Rp. 92.610.000. Biaya operasional kegiatan lahan tambak garam adalah sebesar Rp. 7.248.000/Ha4. Total estimasi biaya operasional tambak garam adalah sebesar Rp. 50.736.000. Dengan demikian nilai manfaat tambak garam di Desa Oeteta adalah sebesar Rp. 41.874.000 dengan asumsi lahan yang digunakan adalah milik pemerintah dan bebas dari biaya sewa. Potensi pemanfaatan lahan sebagai tambak garam masih cukup besar mengingat masih banyak terdapatnya lahan yang belum dimanfaatkan dan 
berpotensi untuk menjadi tambak garam baik yang terdapat di Desa Oeteta atau didaerah Pariti.

\section{Nilai Manfaat Sumberdaya Mangrove}

Nilai manfaat sumberdaya mangrove paling besar diperoleh dari pemanfaatan sumberdaya perikanan tangkap Rp. $56,488,743,820$ (98 persen) terutama udang yang mencapai Rp. 53,304,913,645 atau 94.5 persen dari total pemanfaatan sumberdaya perikanan tangkap.. Menurut Gunarto (2004), perairan mangrove biasanya keruh sehingga akan menghindarkan juvenil udang dari pemangsanya Sehingga ekosistem mangrove secara alami merupakan lingkungan yang sesuai bagi udang untuk memijah dan kondisi yang ideal bagi udang untuk dapat tumbuh semakin besar. Hal ini menunjukkan bahwa kondisi mangrove di wilayah Teluk Kupang masih relatif baik terutama pada wilayah mangrove di sekitar Desa Oeteta dan Pariti. Kondisi tersebut ditunjang oleh kegiatan penanaman pohon mangrove baru yang dilakukan oleh instansi pemerintah setempat. Sebagai contoh proyek pengelolaan sumberdaya pesisir dan laut (MCRMP) yang merupakan kerjasama Bappeda Kabupaten Kupang dan PT. Citra Desain Rekanusa pada tahun 2004 yang menanam pohon bakau jenis Rhizopora (Bruguera Cilindrica) pada lahan seluas 500 m2 di wilayah pantai Desa Oeteta.

Pemanfaatan sumberdaya kayu untuk kayu bakar dan tegakan alat tangkap sero waring menunjukkan nilai yang tidak terlalu besar yaitu Rp.682,140,000 (1.18 persen). Adanya larangan pemanfaatan kayu mangrove secara bebas dan mulai tumbuhnya kesadaran masyarakat akan pentingnya menjaga keberadaan pohon-pohon mangrove membuat pemanfaatan dilakukan secara terbatas. Pada masa-masa mendatang pemanfaatan kayu mangrove masih perlu dibatasi lagi yaitu hanya untuk kayu bakar. Sehingga keberadaan mangrove tetap terjaga bahkan semakin baik.

Pemanfaatan lahan di sekitar mangrove untuk kegiatan pertambakan baik tambak

Tabel 8. Rekapitulasi Nilai Manfaat Langsung Sumberdaya Mangrove di Teluk Kupang Table 8. Recapitulation of Direct Benefit Value of Mangrove Resource in Kupang Bay

\begin{tabular}{|c|c|c|c|c|c|}
\hline \multirow[t]{2}{*}{ No } & \multirow{2}{*}{$\begin{array}{l}\text { Jenis Pemanfaatan/ } \\
\text { Kind of Utilization }\end{array}$} & \multicolumn{3}{|c|}{$\begin{array}{c}\text { Nilai Pemanfaatan (Rp/tahun)I } \\
\text { Utilization Value (Rp/year) }\end{array}$} & \multirow{2}{*}{$\begin{array}{c}\text { Total } \\
\text { (Rp/tahun)/ } \\
\text { Total } \\
\text { (Rp/year) }\end{array}$} \\
\hline & & Pariti & Oeteta & Oebelo & \\
\hline \multirow[t]{5}{*}{1} & $\begin{array}{l}\text { Penangkapan / } \\
\text { Capture }\end{array}$ & & & & \\
\hline & a. Udang / Shrimp & 18.162 .468 .333 & 31.421 .507 .812 & 3.720 .937 .500 & 53.304 .913 .645 \\
\hline & b. Ikan/Fish & 987.026 .175 & 1.238 .625 .000 & 671.400 .000 & 2.897 .051 .175 \\
\hline & c. Kepiting / Crab & 37.440 .000 & 62.400 .000 & 46.475 .000 & 146.315.000 \\
\hline & d. Kerang / Shell & 18.000 .000 & 36.000 .000 & 16.000 .000 & 70.000 .000 \\
\hline \multirow[t]{3}{*}{2} & $\begin{array}{l}\text { Pemanfaatan Kayu/ } \\
\text { Wood Utulization }\end{array}$ & & & & \\
\hline & a. Kayu Bakar/Firewood & 109.330 .000 & 71.136 .000 & 225.424 .000 & 405.890 .000 \\
\hline & $\begin{array}{l}\text { b. Kayu Tegakan Sero } \\
\text { Waring/ Sero Waring } \\
\text { Stand Support Wood }\end{array}$ & 120.275 .000 & 155.975 .000 & - & 276.250 .000 \\
\hline \multirow[t]{4}{*}{3} & $\begin{array}{l}\text { Pemanfaat lahan / } \\
\text { Land Utilization }\end{array}$ & & & & \\
\hline & $\begin{array}{l}\text { a. Tambak Bandeng / } \\
\text { Chanos-chanos Pond }\end{array}$ & 442.164 .706 & - & - & 442.164 .706 \\
\hline & $\begin{array}{l}\text { b. Tambak Garam / } \\
\text { Salt Pond }\end{array}$ & - & 41.874 .000 & - & 41.874 .000 \\
\hline & Total & 19.655.621.861 & 33.027.517.812 & 4.675.258.744 & 57.584.458.526 \\
\hline
\end{tabular}


Tabel 9. Nilai Manfaat Bersih Pemanfaatan Sumberdaya Mangrove di Teluk Kupang Table 9. Net Benefit Value of Mangrove Resources in Kupang Bay

\begin{tabular}{clr}
\hline NO & \multicolumn{1}{c}{$\begin{array}{c}\text { Manfaat Bersih Pemanfaatan Sumberdaya/ } \\
\text { Net Benefit Value of Resources }\end{array}$} & $\begin{array}{r}\text { Nilai (Rp/Ha/Th)/ } \\
\text { Value (Rp/Ha/Year) }\end{array}$ \\
\hline 1 & $\begin{array}{l}\text { Pemanfaatan Sumberdaya Perikanan Tangkap/ } \\
\text { Utilization of Fisheries Capture } \\
\text { a. Udang / Shrimp }\end{array}$ & 159.665 .007 \\
b. Ikan / Fish Catch & 4.375 .116 \\
& C. Kepiting / Crab Catch & 442.183 \\
& d. Kerang / Shell Catch & 211.549 \\
2 & Pemanfaatan kayu / Utilization of Wood & 1.226 .654 \\
3 & Pemanfaat lahan untuk tambak (bandeng dan garam)/ & \\
& Utilization of Land for pond (Fishmilk and Salt) & 5.495 .444 \\
& Total & 171.415 .954 \\
\hline
\end{tabular}

bandeng atau garam belum banyak dilakukan. Nilai dari pemanfaatan lahan sebesar Rp. 442.164.706 atau hanya sebesar 0,8 \% dari nilai total manfaat sumberdaya mangrove. Kegiatan tambak khususnya tambak udang sebenarnya menarik banyak pihak untuk turut serta melakukan usaha. Namun adanya penolakan warga terhadap pembangunan tambak disekitar mangrove, membuat perkembangan kegiatan tambak terhambat. Masyarakat menilai bahwa, pembangunan tambak disekitar kawasan mangrove akan mengurangi hasil tangkapan udang dan ikan pada masa yang akan datang.

Berdasarkan penghitungan terhadap manfaat dan biaya dengan asumsi tingkat discount factor $11 \%$ selama kurun waktu 10 tahun, diketahui pula bahwa pemanfaatan sumberdaya mangrove di Teluk Kupang memiliki manfaat bersih sebesar Rp. $1,666,819,252 /$ ha. Nilai pemanfaatan sumberdaya perikanan tangkap mencapai Rp. 1.646.938.562/ha. Pemanfaatan kayu dan pemanfaatan lahan di sekitar kawasan mangrove masing-masing memiliki nilai manfaat sebesar Rp. 12.266.539/ha dan Rp. 54.954.439. Kondisi akan tercapai dengan asumsi tidak terjadi perubahan tingkat pemanfaatan dalam kurun waktu yang diperhitungkan.

Besar nilai pemanfaatan sumberdaya mangrove oleh masyarakat memberikan pengertian bahwa masyarakat dipesisir Teluk Kupang memiliki ketergantungan yang cukup besar terhadap sumberdaya mangrove yang ada. Oleh karena itu rumusan pengelolaan dan pembangunan wilayah pesisir pada Teluk Kupang, harus mempertimbangkan dampak ekonomi yang secara langsung akan diterima oleh masyarakat. Setiap perubahan sebagai konsekuensi dari adanya kebijakan diwilayah pesisir, akan memberikan pengaruh terhadap tingkat kesejahteraan masyarakat.

\section{KESIMPULAN}

Jenis pemanfaatan sumberdaya mangrove yang ada di Teluk Kupang meliputi pemanfaatan sumberdaya perikanan, pemanfaatan sumberdaya kayu dan pemanfaatan sumberdaya lahan di sekitar wilayah mangrove. Total nilai pemanfaatan sumberdaya mangrove di Teluk Kupang adalah sebesar Rp..57.584.458.526 dengan manfat bersih sebesar Rp. 171.415.954/ha/th. Nilai pemanfaatan sumberdaya mangrove yang terbesar adalah sumberdaya perikanan tangkap yang mencapai $98 \%$ dari nilai total pemanfaatan mangrove. Pemanfaatan kayu mangrove untuk berbagai keperluan masih cukup banyak dilakukan dengan nilai pemanfaatan mencapai Rp. 682.140.000. Bila pemanfaatan 
ini masih terus dilakukan dalam jangka waktu yang cukup lama, dikhawatirkan dapat menekan keberadaan sumberdaya mangrove.

\section{SARAN}

Sebagai lanjutan dari penelitian ini, diperlukan berbagai simulasi pengelolaan wilayah pesisir yang memberikan tingkat keuntungan optimal yang didasarkan pada potensi pemanfaatan ekonomi sumberdaya mangrove yang ada. Selain itu, juga perlu dilakukan penelitian terhadap kemungkinan dampak sosial dan solusi antisipasinya dari setiap perubahan yang menjadi konsekuensi dari lahirnya suatu kebijakan. Dengan demikian, kebijakan dapat berjalan dengan baik dan diterima oleh masyarakat.

\section{DAFTAR PUSTAKA}

Adrianto, L.2006. Sinopsis Pengenalan Konsep dan Metodologi Valuasi Ekonomi Sumberdaya Pesisir dan Laut. Pusat Kajian Sumberdaya Pesisir dan Lautan Institut Pertanian Bogor. Bogor
Anonim.1999. Pemetaan dan Perancangan Program Pengembangan Petani Garam \& Penggarap. Direktorat Jenderal Industri Kimia, Agro dan Hasil Hutan. Rancangan \& Teknik Pemilihan Proyek Percontohan (Demonstration Plot) Produksi Pegaraman Rakyat di Indonesia. Departemen Perindustrian dan Perdagangan. Direktorat Jenderal Industri Kimia, Agro, dan Hasil Hutan. Jakarta

Fauzy ${ }^{1}$. 2003. Persepsi Terhadap Nilai Ekonomi Sumberdaya. Contoh Kurikulum dan Agenda Pelatihan Pengelolaan Sumberdaya Wilayah Pesisir Terpadu. Usaid-Indonesia Coastal Resources Management Project Koleksi Dokumen Proyek Pesisir 1997-2003. Jakarta.

Gunarto, 2004. Konservasi Mangrove Sebagai Pendukung Sumber Hayati Perikanan Pantai. Bogor. Jurnal Litbang Pertanian 23 (1), 2004 hal 15-21.

Kusuma, D Indah. 2005. Economic Valuation Of Natural Resource Management: A Case Study Of The Benuaq Dayak Tribe In Kalimantan, Indonesia (Dissertation). Bogor Institut of Agriculture. Bogor 